\title{
RESOURCE USE IMPACTS WITHIN THE FOREST LAND COVER OF KHANGCHENDZONGA BIOSPHERE RESERVE, SIKKIM HIMALAYA ALONG DIFFERENT DISTURBANCE LEVELS AND ALTITUDINAL ZONES
}

\author{
CHHETRI, S.K. ${ }^{1,2}-$ SINGH, K.K. ${ }^{1} *-$ KRISHNA, A.P. ${ }^{1,3}$ \\ ${ }^{1}$ G.B. Pant Institute of Himalayan Environment and Development, Sikkim Unit, Pangthang, Post \\ Box 24, Gangtok, East Sikkim 737 101, Gangtok, Sikkim, India \\ (phone: +91-03592-237189; fax: +91-03592-03592-237415)
}

${ }^{2}$ Ashoka Trust for Research in Ecology and the Environment, Eastern Himalaya Office, E/2, $2^{\text {nd }}$ Floor, Golden Heights, Gandhi Road, P.O. Darjeeling - 734 101, Dist. Darjeeling, West Bengal, India

${ }^{3}$ Remote Sensing Department, Birla Institute of Technology (BIT), Mesra, Ranchi - 835215 , Jharkhand, India.Email: apkrishna@yahoo.com

*Corresponding author e-mail: singhkk20@yahoo.com or singhkk20@hotmail.com

(Received $17^{\text {th }}$ February 2009; accepted $29^{\text {th }}$ January 2013)

\begin{abstract}
This study has been undertaken to derive resource use impacts on the forest cover vegetation components (species composition, diversity, wood biomass and increment) of Khangchendzonga Biosphere Reserve (KBR). Attempts have been made to seek valuable insight through data analysis along disturbance gradients in different altitudinal zones. Within the KBR landscape, sites corresponding to three levels of disturbances were identified: viz. i) Type III, ii) Type II and iii) Type I based on differing degrees of proximity to habitation. Data analysis revealed disturbance at different levels along all altitudinal gradients to be positively correlated with decrease in values of tree species density, basal area and importance value index (IVI). Generally, number of seedlings and saplings decreased towards proximity of different disturbance levels across all forest sites except in one case. Wood biomass and increment pertinently increased on undisturbed site. It was also observed that diversity is significantly correlated with increase in species richness. Such observations indicate that resource use pressures may lead to substantial impacts on KBR forest cover vegetation. So, in order to curb such future impacts, regular analysis of the ongoing changes and identifying gaps for conservation becomes imperative in this Biosphere Reserve (BR).
\end{abstract}

Keywords: protected area, Khangchendzonga Biosphere Reserve, Sikkim Himalaya, forest land cover, diversity, disturbance gradients, altitudinal zones

\section{Introduction}

Protected area (PA) enforcement and management tend to disregard natural resource use and socio-cultural values of local communities regardless of resource needs for subsistence (Maikhuri et al., 2000; Chettri, 2005). Forest resources are disturbed to a great extent by both natural and anthropogenic use resulting in habitat degradation, and subsequent depletion of flora and fauna. Anthropogenic conversion of natural habitat is the single largest cause of loss of biological diversity and a balance between natural habitat and human-dominated landscape determines its future. Surrogates such as species diversity, regeneration and biomass removal from forest give direct insight into the extent of interaction of man with his biological and physical surroundings (Sarkar and Margule, 2002). Conservation and management of forests require understanding 
species composition of particular forest in relation to other forests, effects of past impacts on present status and their relationship with surrounding land use (Geldenhuys and Murray, 1993). Harvesting of resources for human use causes thinning of woodlands (Griffin and Muick, 1990), affects vegetation structure and composition (Block and Brennan, 1993), reduces canopy structure, and brings about changes in the age and size distribution of stands (Sundriyal and Sharma, 1996; Aigner et al., 1998).

Recently notified Khangchendzonga Biosphere Reserve in Sikkim Himalaya is a part of global biodiversity hotspots. It supports a vast repository of natural resources found between temperate, cold temperate and upto alpine regions. KBR has got several globally important endemic species. These plant wealth become a shelter to many important wild organisms and fundamental source of ecosystem services which not only provide better livelihood opportunities to the local residents but also benefit the surrounding ecosystems at large. The constant and direct use of these forests especially for the needs of local inhabitants in terms of fuel, fodder, and collection of herbal plants and wild edibles adversely affect the forest condition leading to threats of extinction to certain species. As already reported by Lepcha (1997), more than 25 plant species have become endangered so far from the biosphere reserve. Significant among these include Aconitum spp., Taxus baccata, and Rhododendron spp. etc. Moreover, livestock grazing, illegal felling and tourism growth trend are other additional pressure on forest, thus subjecting the ecosystem to great stress and multiple threats.

Although few systematic studies have been done in this important landscape with respect to human dimension and forest composition (Sharma, 1997; Singh, 2000; Chettri, et al., 2002; Krishna et al., 2002; Chettri et al., 2006), resource use pressure studies, vegetation composition of the forest cover and biomass stocking are much needed towards understanding of forest processes. These are fundamental to the management of natural and disturbed vegetation and shall be further necessary for assessment of potential impacts, the reorganisation of disturbance, optimization of productivity and rehabilitation of degraded ecosystems (Congden and Herbohn, 1993).

Major objective of this study is to address the issue of resource use impacts in terms of status of species (woody tree species) composition, diversity, regeneration potential (seedling + sapling number per unit area), existing wood biomass, and their increment (branch + bole) in disturbed, partially disturbed and undisturbed stands in four altitudinal zones of KBR forest land cover ranging between $1670 \mathrm{~m}-2730 \mathrm{~m}$. While decrease in tree density ultimately led to low species diversity and biomass accumulation towards increased disturbance levels representing major indicators of persistent human pressure in the region. In addition, severe impacts of reduction in species structure and composition in some disturbed stands have been experienced due to heavy utilization of such sites. Apart from such, this study will underline for identifying various forms of human resource use pressures in a recently notified biosphere reserve. Also, this protected area is one of the highest ecosystems in the world and the study was carried out in such a place where the existing flora and fauna are exceptionally unique and diverse, experiencing pressures from external reasons that depend mainly on different religio-cultural practices of number of ethnic tribes residing in the vicinity of biosphere reserve. 


\section{Study area and climate}

This study has been carried out in the Khangchendzonga Biosphere Reserve (KBR) falling within the geo-coordinates $27^{\circ} 25^{\prime}$ and $27^{\circ} 55^{\prime} \mathrm{N}$ latitude and $88^{\circ} 03^{\prime}$ and $88^{\circ} 38^{\prime} \mathrm{E}$ longitude. Khangchendzonga is a unique mountain ecosystem falling within three different national boundaries of India, Nepal and China (Tibetan Autonomous Region). It has a total area of 2620 sq. km; a core zone of 1784 sq. km and four buffer zones comprising $836 \mathrm{sq}$. $\mathrm{km}$. These altogether constitutes 37 percent area of the total geographic area of Sikkim. The lowest point of KBR measures $1220 \mathrm{~m}$ and the highest $8598 \mathrm{~m}$ asl. For the present investigation, four important elevations were considered, viz. 1) one low elevation (1670 m) at Sakyong-Pentong in the north district, 2) and 3) two mid elevations (1780 and $2190 \mathrm{~m}$ ), Yuksam and Uttaray respectively in the west, and 4) one high elevation $(2730 \mathrm{~m})$, at Lachen in the north. These are shown in the Geographical Information System (GIS) generated map of KBR (Fig. 1). They represent different altitudinal gradients as mentioned, vegetation types vis-à-vis extent of resource use pressures.

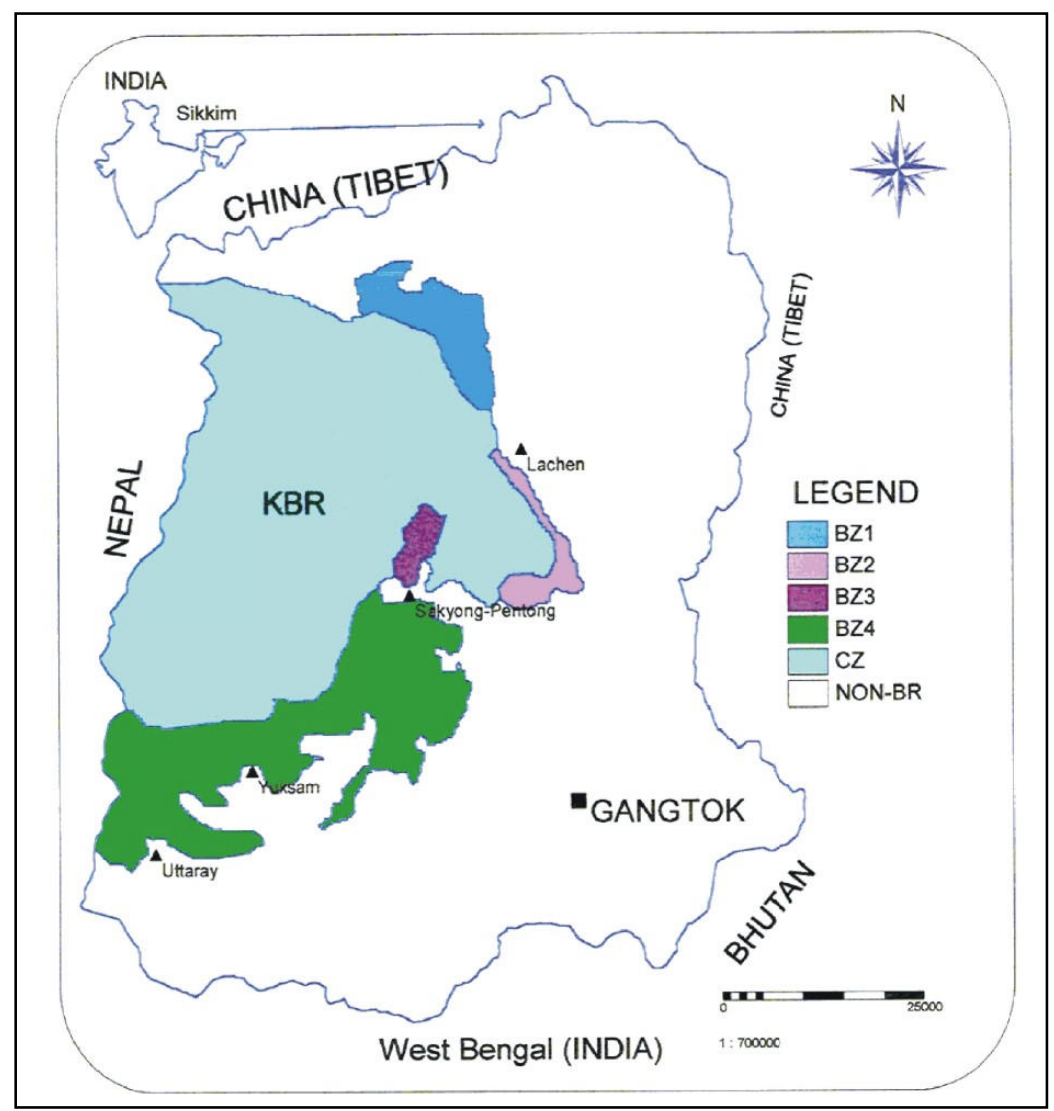

Figure 1. Location map of Khangchendzonga Biosphere Reserve, Sikkim Himalaya prepared using GIS and showing the study sites (after Chhetri et al., 2006)

Fig. 2 shows land use/land cover map of KBR derived from Indian Remote-Sensing Satellite (IRS) data of 1999 (Chettri et al., 2006). Within its forest land cover, KBR has unique vegetation types with diverse plant communities, such as, (i) Dense mixed/conifer forest (ii) Open mixed/conifer forest/silver fir-Rhododendron forest (iii) Degraded mixed/conifer forest (iv) Scrub land/forest blanks, and (v) Alpine 
scrub/pasture land. The above stated low elevation forest type within the BR is found in the proximal end of buffer zones (BZs) III and IV and core zone (CZ) whereas, mid elevation forests are found in the region of BZ-IV and high elevation forest is present close to BZ-I and CZ. Average annual rainfall of the study areas ranges from 3500 to $4000 \mathrm{~mm}$. Minimum and maximum temperatures recorded at sub-alpine and alpine areas were below zero degree centigrade whereas, average minimum and maximum temperatures of temperate zones were recorded between $12^{\circ} \mathrm{C}$ and $16.9^{\circ} \mathrm{C}$.

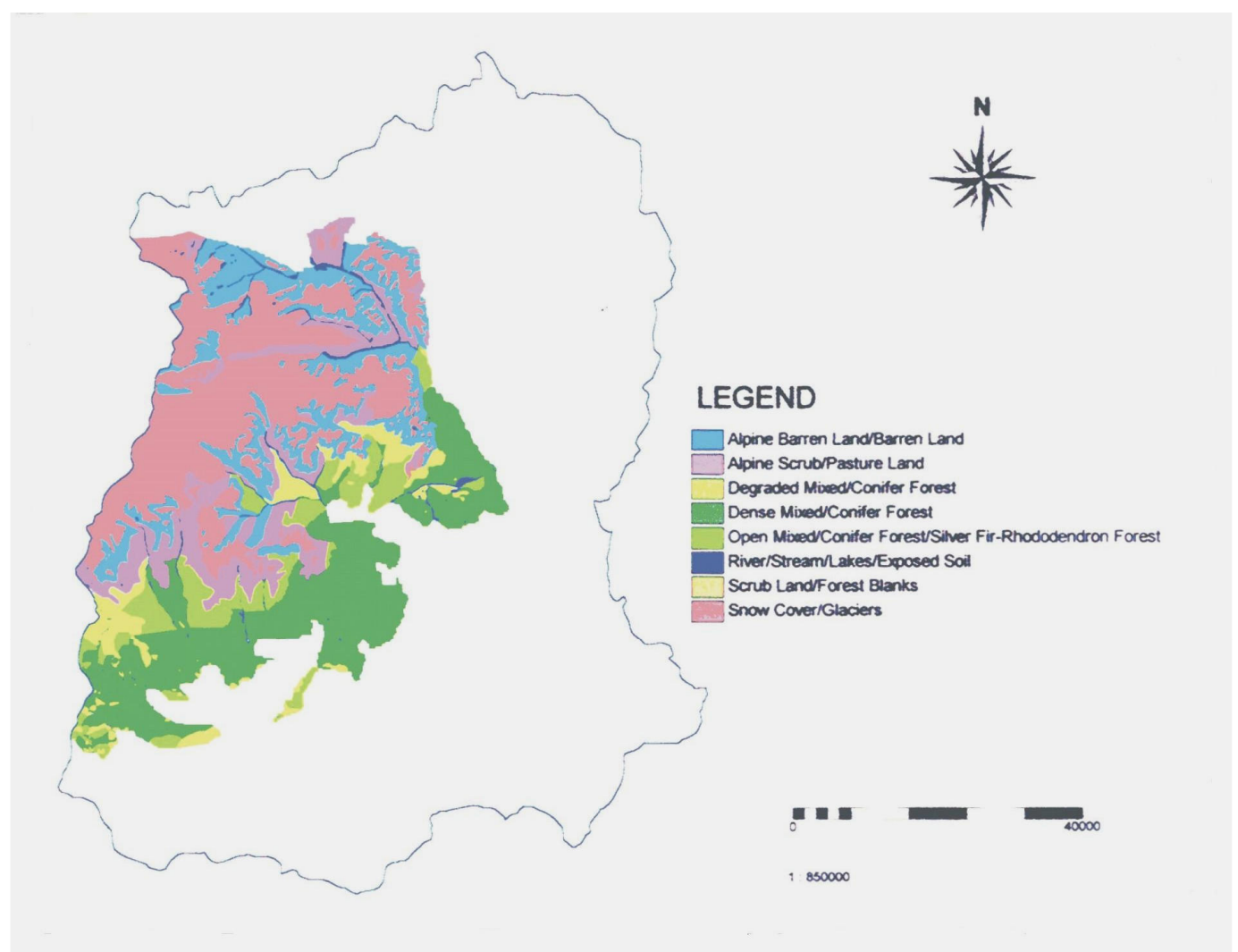

Figure 2. Land use/land cover map of KBR derived from Indian Remote-Sensing Satellite (IRS) data of 1999 (after Chhetri et al, 2006)

\section{Materials and methods}

The four altitudinal sites of KBR forest considered for the study such as Low altitude forest laid at Sakyong-Pentong has temperate forests dominated by Castanopsis tribuloides. The aspect is south east facing and slope $45^{\circ}$, soil type is loamy and the air temperatures ranging from $20-25^{\circ} \mathrm{C}$. Whereas, Mid altitude I taken at Yuksam has got temperate forests dominated by broad-leaved Glochidion acuminatum. The aspect here is south west and slope $5^{\circ}$ with soil texture clayey black and the air temperatures varying from $16-20{ }^{\circ} \mathrm{C}$. Mid altitude II forest studied at Uttaray too has temperate forests with dominant Quercus sp. The aspect is south west and slope $5^{\circ}$, soil type is blackish clayey in colour whereas the air temperatures ranging from $12-16{ }^{\circ} \mathrm{C}$. High altitude forest chosen at Lachen comprises of cold temperate forest dominated by Abies densa and Rhododendron sp. Soil type found is sandy and the air temperature range is 1 to $6^{\circ} \mathrm{C}$, south east aspect and a slope of $63^{\circ}$. 
Three different a priori defined disturbance levels in each forest type (elevation zone) were selected based on the fixed distance from human settlements during the years 2000 to 2004. These levels were categorised as disturbed stand (between 1-2 km), partially disturbed stand (between 2-4 km) and undisturbed stand $(>4 \mathrm{~km})$ and called Types I (TI), II (T-II) and III (T-III) for nomenclature respectively. Composition of tree species was analysed using $10 \times 10 \mathrm{~m}$ quadrats in each T-I, T-II and T-III levels for different elevation sites, numbering a total of 84 quadrats separately considering them within a belt-like transect following Mueller-Dombois and Ellenberg (Mueller Dombois and Ellenberg, 1974). Those $10 \times 10 \mathrm{~m}$ quadrats were put at a distance of $10 \mathrm{~m}$ apart. Environmental factors such as aspect, slope were measured for those designated quadrats. As such quadrats measuring $10 \times 10 \mathrm{~m}$ were considered and used to analyse species structure and compositions for the species present once a year and then left them for ever.

In addition, 36 sub-quadrats measuring $1 \times 1 \mathrm{~m}$ were studied for assessing number of seedlings and saplings in T-I, T-II and T-III disturbance levels for forest elevation zones being studied. All individuals were separated into three categories viz., seedling (height $<20 \mathrm{~cm}$ ), sapling (height $>20 \mathrm{~cm}$ and $\mathrm{dbh}<10 \mathrm{~cm}$ ), and tree $(\mathrm{dbh}>30 \mathrm{~cm}$ ). Circumference at breast height (cbh) of each tree species was measured and then converted to diameter at breast height (dbh). Height of trees were determined using Clinometer. Trees were grouped into different dbh class sizes. Crown cover was also measured from the stands. Density $\left(\right.$ trees $\left.\mathrm{ha}^{-1}\right)$ and basal area $\left(\mathrm{m}^{2} \mathrm{ha}^{-1}\right)$ were calculated (basal areas of the trees were quantified to find out the basal cover of the tree measured at $1.3 \mathrm{~m}$ breast height), followed by calculation of species abundance/frequency (A/F) ratio (Whitford, 1949). Importance Value Index (IVI) for tree species was calculated (Philips, 1959). Number of seedlings and saplings was recorded for each replicate stand (Bonham, 1989). Species diversity was determined following Shannon-Wiener's (1963) method. Species richness (Margalef, 1957) and concentration of dominance (Simpson, 1949) were calculated for predicting strongest control/cover of species over space at different locations within the forest.

\section{Analysis and calculations}

Tree diversity determination was done using Shannon-Wiener index, 1963 as this mainly reflects the number of species and the proportion of individuals of the species in an ecosystem.

Thus, formula for diversity is $\quad H^{\prime}=-\Sigma\left[\left(p_{i}\right)\left(\ln p_{i}\right)\right]$

$$
\text { Alternatively: } \quad H^{\prime}=-\Sigma[(\mathrm{n} / \mathrm{N})(\ln \mathrm{n} / \mathrm{N})]
$$

Where, $\mathrm{p}_{\mathrm{i}}$ is the proportion of the $\mathrm{i}^{\text {th }}$ species in a given habitat, $\mathrm{n}$ is the number of individuals of a species in a given sample, and $\mathrm{N}$ is the total number of species in a given sample.

(ii) Margalef's index, $\quad \mathrm{R} 1=\mathrm{s}-1 / \ln (\mathrm{n})$

whereas, $\mathrm{s}$ is the number of species, $\mathrm{n}$ is the number of individuals of a species. 
(iii) Simpson's index of dominance is the sum of square of all $p_{i}$ values for all species in the community:

$$
\mathrm{C}=\Sigma\left(\mathrm{p}_{\mathrm{i}}\right)^{2}
$$

$$
\text { Total basal area }=\pi r^{2} \times D
$$

Where, $\pi=$ radius at stem, $\mathrm{D}=$ density

Tree wood biomass and increment (branch + bole) were studied from three different disturbance levels in each elevation. For this, thirty-six such permanent quadrats of $20 \times$ $20 \mathrm{~m}$ (i.e. three in each T-I, T-II and T-III disturbance levels for different forest elevations) were laid separately during 2003 - 2004 (Trivedi et al., 1987). These quadrats were put permanently, and kept under strict vigil except than some unseen human activities that took place, determined the dbh and heights of the trees for two consecutive years, to effectively understand the annual wood increment patterns. Estimation of standing biomass was done for selected species only. Stumps of trees felled from the plots were counted and their dbh determined. Height of removed trees was estimated based on the relative dimensions of same standing species; and biomass was then estimated using allometric equations specific to the species (Ruark et al., 1987; Anderson and Ingram, 1993; Sundriyal et al., 1994). Annual wood biomass production was estimated following Grier and Logan (Grier and Logan, 1997). Statistical analyses were done using software Systat Ver. 6.0 (1996).

\section{Results}

\section{Species structure}

Number of species encountered in four different elevation zones showed that the lowest elevation had the highest species number (23) and the highest elevation zone had the lowest species number (6) as presented in the Tables $1 a, 1 b, 1 c$ and $1 d$. Tree density showed a declining trend from T-III to T-I in all the four elevations. In $2190 \mathrm{~m}$, unusually a high density (555 trees $\mathrm{ha}^{-1}$ ) of Eurya acuminata in T-I relative to tree densities in T-II ( 67 trees $\left.\mathrm{ha}^{-1}\right)$ and T-III $\left(45\right.$ trees $\left.^{-1} \mathrm{ha}^{-1}\right)$ may be attributed to it being a secondary successional species. Tree densities at different disturbance levels along four altitudes are shown in the Fig. 3.

Values of $\mathrm{A} / \mathrm{F}$ ratio for all species showed a decreasing trend from T-III to T-I. In TIII of $1780 \mathrm{~m}$ and $2190 \mathrm{~m}$, the number of regular species increased than that in T-I. If $\mathrm{A} / \mathrm{F}$ ratio $<0.025$, the distribution will be regular, between 0.025 to 0.05 it will be random and if $>0.05$, it becomes contagious (Curtis and Cottam, 1956). This means the $\mathrm{A} / \mathrm{F}$ ratio pattern along all elevations as observed was T-I (0.01-0.17), T-II (0.01-0.09) and T-III (0.01-0.24). Basal area was highest $\left(53 \mathrm{~m}^{2} \mathrm{ha}^{-1}\right)$ in T-III of $2730 \mathrm{~m}$ due to high tree density and the lowest $\left(10.8 \mathrm{~m}^{2} \mathrm{ha}^{-1}\right)$ recorded in T-I of $2730 \mathrm{~m}$ (Fig. 4). Basal area ranged between $40.3-53.0 \mathrm{~m}^{2} \mathrm{ha}^{-1}$ in T-III, $25.5-40.0 \mathrm{~m}^{2} \mathrm{ha}^{-1}$ in T-II, and $10.8-35.0$ $\mathrm{m}^{2} \mathrm{ha}^{-1}$ in T-I. 


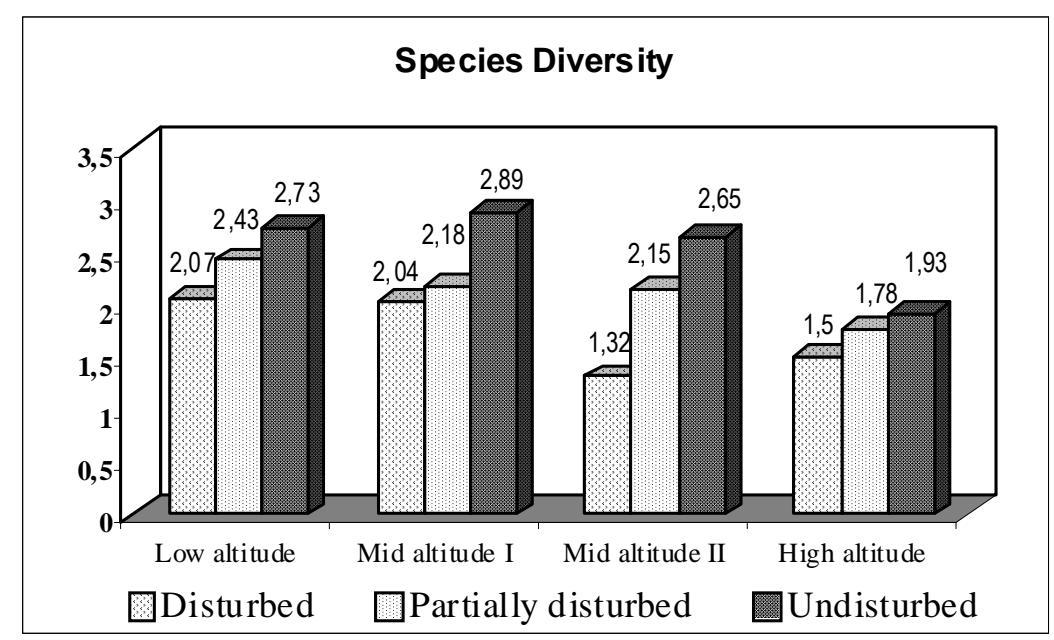

Figure 3. Species diversity in Type I, Type II and Type III disturbance levels in an altitudinal gradients

Importance Value Index (IVI) was recorded maximum for Eurya acuminata (116.6) in T-I of $2190 \mathrm{~m}$ (Table 4). Machilus edulis having IVI value (76.2) was dominant in TI of $1670 \mathrm{~m}$, Alnus nepalensis (84.6) and Toona ciliata (73.9) were found codominating the forest in $1780 \mathrm{~m}$, undoubtedly, Eurya acuminata in T-I of $2190 \mathrm{~m}$ constituted a bulk of vegetation. Whereas, Juniperus sp. (71.8) and Tsuga brunoniana (69.4) in $2730 \mathrm{~m}$ were major species. This result is comparable with the study of tree dominance in temperate forests of Darjeeling Hills, India made by Kapoor et al. (1989).

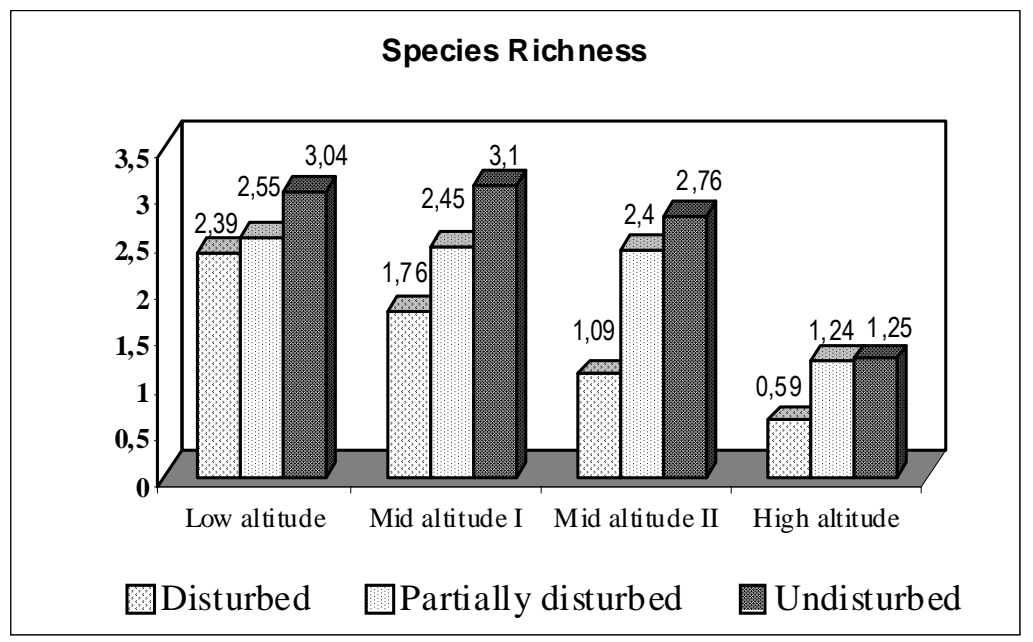

Figure 4. Species richness in Type I, Type II and Type III disturbance levels along altitudinal gradients

Shannon-Wiener's index, Margalef's index, and Simpson's index all showed their higher values in T-III, medium in T-II and lowest in T-I. Species diversity ranged from 1.93 to 2.89 in T-III, 1.78 to 2.43 in T-II and 1.32 to 2.07 in T-I (Fig. 3). Species richness was highest in T-III (3.10) of $1780 \mathrm{~m}$; medium in T-II (2.55) of $1670 \mathrm{~m}$ and least in T-I (0.59) of $2730 \mathrm{~m}$ (Fig. 4). Whereas, dominance index was calculated highest 
in T-III of $2190 \mathrm{~m}(0.51)$, in T-II of $2730 \mathrm{~m}(0.33)$ and lowest in T-I (0.13) of both 1670 $\mathrm{m}$ and $2190 \mathrm{~m}$ (Fig. 5).

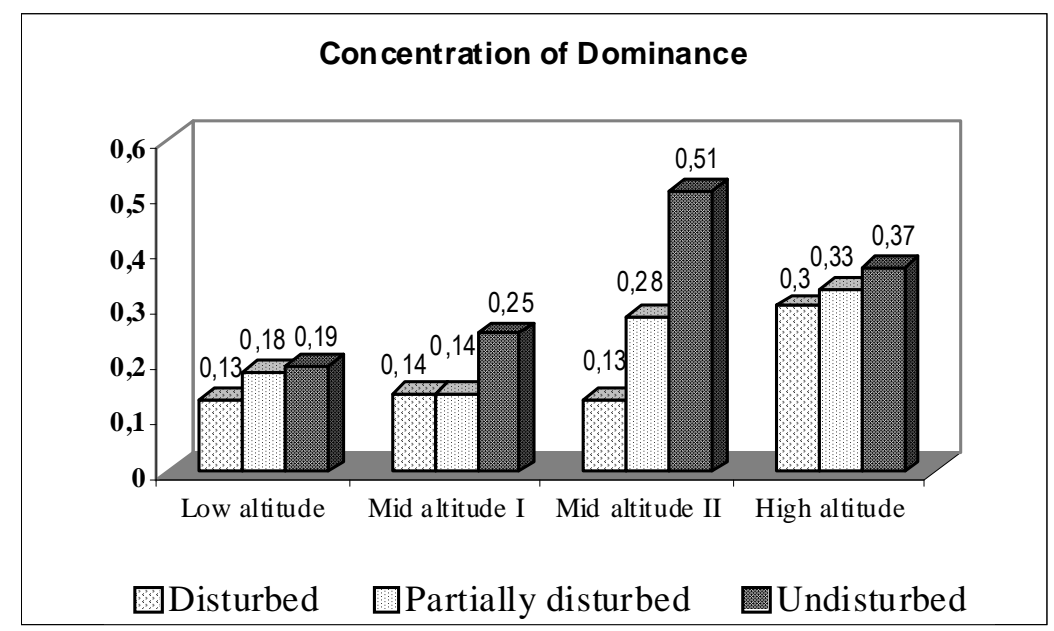

Figure 5. Concentration of dominance in Type I, Type II and Type III disturbance levels along altitudinal gradients

\section{Seedling and sapling}

Presence of seedlings and saplings (seedling/sapling ha ${ }^{-1}$ ) was generally better in TIII than in T-I or in T-II. The seedling number was the highest in T-III (3580 seedling $\left.\mathrm{ha}^{-1}\right)$, T-II (2550 seedling ha $\left.{ }^{-1}\right)$ and T-I (2120 seedling ha $\left.{ }^{-1}\right)$ of $1670 \mathrm{~m}$, which can be attributed to presence of low anthropogenic and grazing pressures at this altitude (Table 2). However, seedling density in T-II (2240 seedling ha $\left.{ }^{-1}\right)$ and T-I (2100 seedling ha $\left.{ }^{-1}\right)$ of $2730 \mathrm{~m}$ was more than the seedling density of T-III (1585 seedling ha $\left.{ }^{-1}\right)$. This was probably due to cold climatic conditions at $2730 \mathrm{~m}$. A comparable highest sapling density was observed in T-III (1455 sapling ha ${ }^{-1}$ ) of $1670 \mathrm{~m}$, T-II (1280 sapling ha $\left.{ }^{-1}\right)$ in $2190 \mathrm{~m}$ and T-I (1050 sapling $\left.\mathrm{ha}^{-1}\right)$ in $1780 \mathrm{~m}$ (Table 5).

\section{Wood biomass and increment}

Across all elevations, the biomass and yearly net increment in tree bole and branch were more in T-III than the biomass and annual increment in T-I or T-II (Tables $6 \&$ 7). While T-III of $2190 \mathrm{~m}$ was the most productive site $\left(436.7 \mathrm{t} \mathrm{ha}^{-1}\right)$ and T-I of $2730 \mathrm{~m}$ was the least productive site $\left(65.0 \mathrm{t} \mathrm{ha}^{-1}\right)$, and annual wood increment showed an increasing pattern towards decreasing pressure as shown in the Table 6. Wood biomass of the major tree species was estimated using exponential regression equations developed for the temperate forests (Sundriyal et al., 1994). Allometric equations used are presented in the Table 8. 
Table 1. Density (trees $\left.h a^{-1}\right)$, abundance frequency ratio $(A / F)$, basal area $\left(B A=m^{2} h a^{-1}\right)$ and Importance Value Index (IVI) of tree species in T-I, T-II and T-III of Low Altitude buffer forest $(1670 \mathrm{~m})$

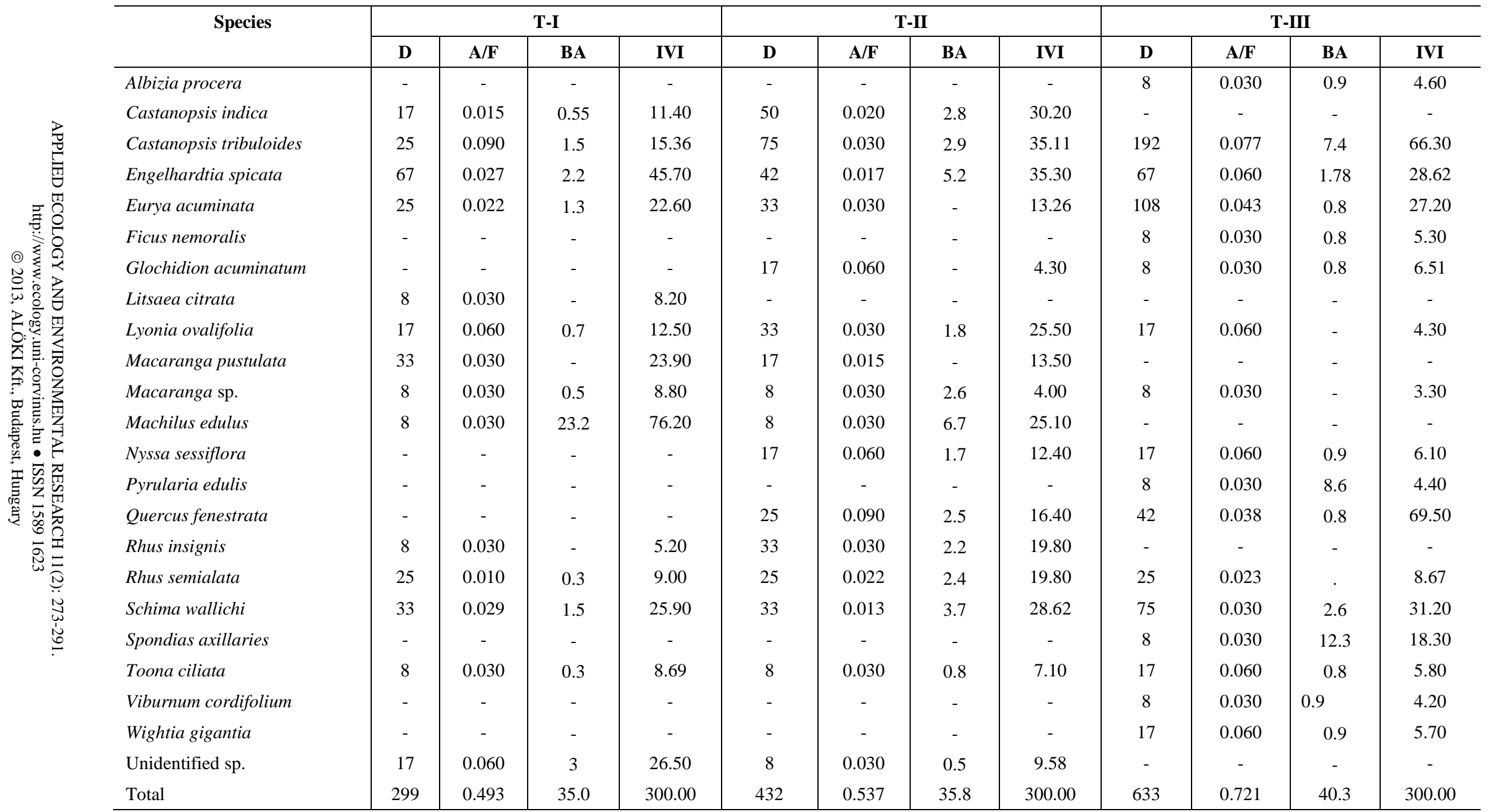


Table 2. Density (trees $\left.h a^{-1}\right)$, abundance frequency ratio $(A / F)$, basal area $\left(B A=m^{2} h a^{-1}\right)$ and Importance Value Index (IVI) of tree species in T-I, T-II and T-III of Mid-Altitude-I buffer forest $(1780 \mathrm{~m})$

\begin{tabular}{|c|c|c|c|c|c|c|c|c|c|c|c|c|}
\hline \multirow{2}{*}{ Species } & \multicolumn{4}{|c|}{ T-I } & \multicolumn{4}{|c|}{ T-II } & \multicolumn{4}{|c|}{ T-III } \\
\hline & D & $\mathbf{A} / \mathbf{F}$ & BA & IVI & D & $\mathbf{A} / \mathbf{F}$ & BA & IVI & D & $\mathbf{A} / \mathbf{F}$ & BA & IVI \\
\hline Acorocarpus fraxinifolia & - & - & - & - & - & - & - & - & 50 & 0.020 & 7 & 48.01 \\
\hline Alnus nepalensis & 33 & 0.013 & 11.54 & 84.60 & 8 & 0.030 & 5.25 & 24.26 & - & - & - & - \\
\hline Brassaiopsis mitis & 42 & 0.017 & - & 51.60 & 50 & 0.020 & 2.5 & 32.50 & - & - & - & - \\
\hline Bucklandia populnea & - & - & - & - & 25 & 0.022 & 4.3 & 31.49 & 58 & 0.023 & 2.1 & 21.40 \\
\hline Castanopsis tribuloides & - & - & - & - & 33 & 0.030 & 2.76 & 29.14 & - & - & - & - \\
\hline Cryptomaria japonica & 17 & 0.060 & 1.36 & 24.59 & - & - & - & - & - & - & - & - \\
\hline Engelhardtia spicata & - & - & - & - & 75 & 0.030 & 3.5 & 43.00 & 67 & 0.027 & 6.48 & 29.68 \\
\hline Eurya acuminata & - & - & - & - & 50 & 0.020 & 0.8 & 26.00 & 50 & 0.020 & 2.3 & 20.30 \\
\hline Glochidion acuminatum & - & - & - & - & - & - & - & - & 142 & 0.057 & 8.25 & 45.40 \\
\hline Jambosa kurji & - & - & - & - & - & - & - & - & 50 & 0.020 & 1.4 & 19.30 \\
\hline Lyonia ovalifolia & - & - & - & - & - & - & - & - & 38 & 0.022 & - & 10.40 \\
\hline Macaranga indica & 17 & 0.060 & 0.5 & 20.69 & 83 & 0.033 & 0.5 & 31.70 & - & - & - & - \\
\hline Michelia cathacarti & - & - & - & - & - & - & - & - & 58 & 0.023 & 8 & 29.40 \\
\hline Paveta indica & - & - & - & - & - & - & - & - & 17 & 0.008 & 3.5 & 18.40 \\
\hline Rhus insignis & - & - & - & - & 50 & 0.020 & 2.8 & 31.40 & 17 & 0.015 & 5.27 & 16.29 \\
\hline Symplocos theifolia & - & - & - & - & 33 & 0.029 & 0.58 & 19.10 & - & - & - & - \\
\hline Toona ciliata & 25 & 0.022 & 12.1 & 73.89 & - & - & - & & - & - & - & - \\
\hline Vitex heterophylla & - & - & - & - & - & - & - & - & 83 & 0.033 & 1.48 & 25.01 \\
\hline Unidentified sp. & 42 & 0.017 & - & 44.58 & 25 & 0.022 & 4.3 & 31.40 & 33 & - & 0.5 & 16.40 \\
\hline Total & 176 & 0.189 & 25.5 & 300.00 & 432 & 0.256 & 27.3 & 300.00 & 663 & 0.268 & 46.3 & 300.00 \\
\hline
\end{tabular}


Table 3. Density (trees $\left.h a^{-1}\right)$, abundance frequency ratio $(A / F)$, basal area $\left(B A=m^{2} h a^{-1}\right)$ and Importance Value Index (IVI) of tree species in T-I, T-II and T-III of Mid Altitude-II buffer forest $(2190 \mathrm{~m})$

\begin{tabular}{|c|c|c|c|c|c|c|c|c|c|c|c|c|}
\hline \multirow[t]{2}{*}{ Species } & \multicolumn{4}{|c|}{ T-I } & \multicolumn{4}{|c|}{ T-II } & \multicolumn{4}{|c|}{ T-III } \\
\hline & D & $\mathbf{A} / \mathbf{F}$ & BA & IVI & $\mathbf{D}$ & $\mathbf{A} / \mathbf{F}$ & BA & IVI & D & $\mathbf{A} / \mathbf{F}$ & $\mathbf{B A}$ & IVI \\
\hline Acer osmatoni & - & - & - & - & 55 & 0.040 & 1.3 & 9.90 & 83 & 0.033 & 8.45 & 34.65 \\
\hline $\begin{array}{l}\text { Cinnamomum } \\
\text { impressinervium }\end{array}$ & 33 & 0.030 & 3.5 & 22.70 & 117 & 0.050 & 1.5 & 28.60 & - & 0.060 & 0.9 & 8.70 \\
\hline Endospermum chinense & - & - & - & - & 25 & 0.023 & 1.5 & 20.00 & 103 & 0.053 & 4 & 35.50 \\
\hline Eurya acuminata & 555 & 0.170 & 8.45 & 116.55 & 67 & 0.030 & 8.2 & 30.25 & 45 & 0.02 & 10.01 & 29.40 \\
\hline Lindera assamica & - & - & - & - & - & - & - & - & 24 & 0.01 & 2.5 & 22.70 \\
\hline Litsaea citrata & - & - & - & - & 8 & 0.030 & 0.5 & 6.70 & 50 & 0.02 & 0.6 & 15.60 \\
\hline Lyonia ovalifolia & 13 & 0.010 & 12.7 & 62.20 & 8 & 0.030 & 1.4 & 11.50 & 67 & 0.027 & 2 & 22.00 \\
\hline Machilus edulis & - & - & - & - & 88 & 0.050 & 3.2 & 24.58 & - & - & - & - \\
\hline Quercus lamellosa & - & - & - & - & 103 & 0.044 & 8.3 & 54.30 & - & - & - & - \\
\hline Quercus lineata & - & - & - & - & 115 & 0.040 & 1.3 & 29.36 & - & - & - & - \\
\hline Quercus sp. & - & - & - & - & 192 & 0.080 & 7.01 & 47.40 & 408 & 0.243 & 8.45 & 70.45 \\
\hline Symplocos sumuntia & 26 & 0.010 & 4.7 & 38.30 & 42 & 0.040 & 5 & 16.00 & 41 & 0.017 & 3 & 20.00 \\
\hline Symplocos theifolia & 100 & 0.010 & - & 14.45 & 100 & 0.040 & 0.8 & 21.40 & 86 & 0.043 & 1.75 & 23.79 \\
\hline Unidentified sp. & 33 & 0.070 & 3.1 & 45.80 & - & - & - & - & 35 & 0.017 & 0.8 & 17.20 \\
\hline Total & 760 & 0.300 & 32.5 & 300.00 & 920 & 0.497 & 40.0 & 300.00 & 942 & 0.543 & 42.5 & 300.00 \\
\hline
\end{tabular}


Table 4. Density (trees $\left.h a^{-1}\right)$, abundance frequency ratio $(A / F)$, basal area $\left(B A=m^{2} h a^{-1}\right)$ and Importance Value Index (IVI) of tree species in T-I, T-II and T-III of High Altitude buffer forest $(2730 \mathrm{~m})$

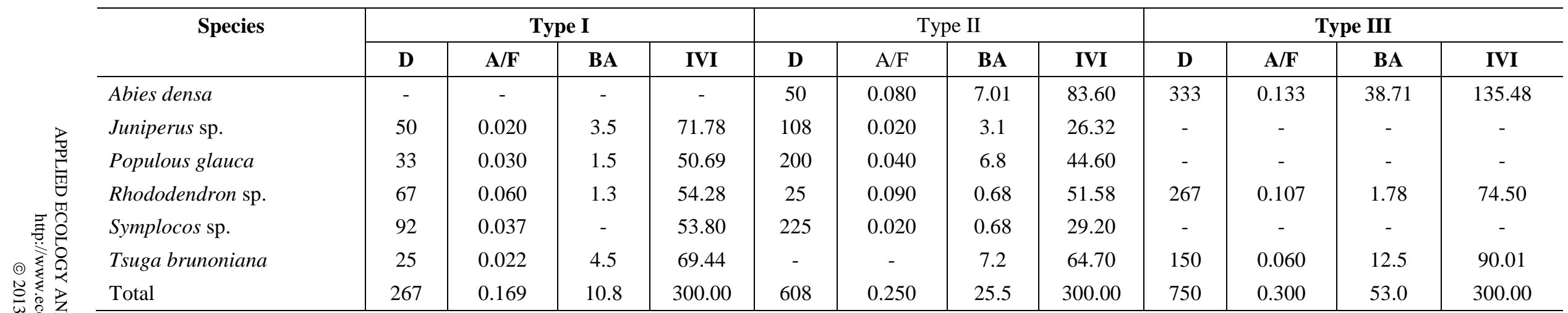

(-) Indicates, species and their values were not obtain 


\section{Discussion}

Resource requirement was generally met from disturbed and partially disturbed stands in KBR forests. The yearly felling of trees and persistent anthropogenic pressure in disturbed and partially disturbed stands have affected the natural regeneration in these levels. In the present study, undisturbed stands generally had higher values of tree density, A/F ratio and basal area. This highlighted that increased disturbance have reduced basal area etc. There appeared more number of random species than number of regular species throughout the study sites as evidenced by Curtis and Cottam (Curtis and Cottam, 1956). From this, it may be assumed that those species were not getting suitable growing conditions. Tree density in climax forests also depends on the levels of resource extraction by humans either as seeds or in mature stage (Kadavul and Parthasarathy, 1998). The confidence interval for density was found to be $95 \%$ at 0.05 significance level. The abnormally large tree basal area recorded in some degraded sites could lead to incorrect interpretation. The primary reason for not felling the larger trees in degraded stands could be that the locals prefer to cut down the young trees, which are easier to transport in hilly terrain and thus remained unnoticed by the authority.

Table 5. Basal area, tree density (trees $\left.h^{-1}\right)$ and seedling and sapling number in the buffer zone forests of $K B R$

\begin{tabular}{|c|c|c|c|c|}
\hline \multirow{2}{*}{ Settlements } & \multirow{2}{*}{ Parameters } & \multicolumn{3}{|c|}{ Forest sites } \\
\hline & & Type I & Type II & Type II \\
\hline \multirow{4}{*}{ Low Altitude } & Tree density $\left(\right.$ trees $\left.\mathrm{ha}^{-1}\right)$ & 299 & 432 & 633 \\
\hline & Basal area $\left(\mathrm{m}^{2} \mathrm{ha}^{-1}\right)$ & 35.0 & 35.8 & 40.3 \\
\hline & Number of seedling $\mathrm{ha}^{-1}$ & 2120 & 2550 & 3580 \\
\hline & Number of sapling ha ${ }^{-1}$ & 930 & 1210 & 1455 \\
\hline \multirow{4}{*}{ Mid-Altitude-I } & Tree density (trees ha ${ }^{-1}$ ) & 176 & 432 & 663 \\
\hline & Basal area $\left(\mathrm{m}^{2} \mathrm{ha}^{-1}\right)$ & 25.5 & 27.3 & 46.3 \\
\hline & Number of seedling $\mathrm{ha}^{-1}$ & 2110 & 2300 & 3525 \\
\hline & Number of sapling ha $^{-1}$ & 1050 & 1265 & 1335 \\
\hline \multirow{4}{*}{ Mid-Altitude-II } & Tree density $\left(\right.$ trees $\left.h a^{-1}\right)$ & 760 & 920 & 942 \\
\hline & Basal area $\left(\mathrm{m}^{2} \mathrm{ha}^{-1}\right)$ & 32.5 & 40.0 & 42.5 \\
\hline & Number of seedling $\mathrm{ha}^{-1}$ & 2000 & 2100 & 3200 \\
\hline & Number of sapling ha ${ }^{-1}$ & 890 & 1280 & 1420 \\
\hline \multirow{4}{*}{ High Altitude } & Tree density (trees ha ${ }^{-1}$ ) & 267 & 608 & 750 \\
\hline & Basal area $\left(\mathrm{m}^{2} \mathrm{ha}^{-1}\right)$ & 10.8 & 25.5 & 53.0 \\
\hline & Number of seedling $\mathrm{ha}^{-1}$ & 2100 & 2240 & 1585 \\
\hline & Number of sapling ha ${ }^{-1}$ & 750 & 975 & 1030 \\
\hline
\end{tabular}


Crown cover had been lost in disturbed stand for a quite long time and was evidenced by the presence of early successional species, like Eurya acuminata in 2190 $\mathrm{m}$ elevation. In many areas secondary successional species have replaced the primary species in disturbed stand. The abundance of Eurya acuminata in disturbed stand of $2730 \mathrm{~m}$ indicated the secondary nature of forest. This species is known to dominate the forest after the clearance of primary forests of Sikkim Himalaya (Jain, 2000). The subalpine forests seem to be more vulnerable to anthropogenic pressures as stress of unfavourable environment increases with altitude. For example, in disturbed stand of $2730 \mathrm{~m}$ crown cover was scanty.

Table 6. Standing wood (branch+bole) biomass $\left(t h a^{-1}\right)$ in T-I, T-II and T-III in buffer zone forests of KBR for the years 2000 and 2001

\begin{tabular}{l|c|c|c|c}
\hline \multirow{2}{*}{ Forest type } & \multirow{2}{*}{ Forest stands } & \multicolumn{2}{|c|}{ Standing biomass } & $\begin{array}{c}\text { Confidence } \\
\text { interval }\end{array}$ \\
\cline { 3 - 4 } Low altitude & T-I & 245.8 & 254.2 & \\
& T-II & 270.0 & 279.2 & \\
& T-III & 325.8 & 339.2 & \\
Mid altitude-I & T-I & 173.3 & 177.5 & \\
& T-II & 195.0 & 209.2 & \\
& T-III & 433.3 & 448.3 & \multirow{2}{*}{$95 \%$} \\
Mid altitude-II & T-I & 272.5 & 285.8 & \\
& T-II & 317.5 & 323.3 & \\
High altitude & T-III & 436.7 & 451.6 & \\
& T-I & 65.0 & 72.5 & \\
& T-II & 202.5 & 210.8 & \\
\hline
\end{tabular}

Certain relationships among forest community characters across study sites were evident. With a varying ecocline diversity in KBR remained high up to $2500 \mathrm{~m}$ and decreased towards higher altitudes. Disturbed stand of these forest conditions had much lower values of diversity (1.32-2.07) and richness (0.59-2.39) than the diversity and richness in undisturbed stands (1.93-2.89 and 1.25-3.10, respectively) as evidenced by Kadavul and Parthasarathy (1998) while studying the biodiversity of woody species in Eastern Ghats. The values of species diversity and richness obtained in the present study were somewhat lower than that reported by Parthasarathy (2001) in KalakadMundanthurai Tiger Reserve, South India. As expected, species richness and species diversity was positively correlated. The confidence level for diversity remained $95 \%$ at 0.05 level of significance. At all sites, human disturbance monotonically reduced species diversity. Generally, species diversity is said to peak at intermediate disturbance level (Whittaker, 1975). In this study Shannon-Wiener's index declined with increasing disturbance. Species richness declined with altitude; its upper limit remained high up to $2600 \mathrm{~m}$, and then declined sharply. This relationship is similar to that reported for Central Himalayan altitudinal transect by Singh et al. (1994). Relationship drawn between species diversity and richness in disturbed, partially disturbed and undisturbed 
stands showed that both are positively correlated along the altitudinal gradients. It was highly significant at 0.0005 level $\left(\mathrm{r}^{2}=0.86, \mathrm{P}<0.0005\right)$.

Table 7. Yearly increment in wood $\left(t h a^{-1} y r^{-1}\right)$ from the buffer zone forests of KBR

\begin{tabular}{|c|c|c|}
\hline Forest type & Forest stands & Increment $\left(\mathrm{t} \mathrm{ha}^{-1} \mathrm{yr}^{-1}\right)$ \\
\hline \multirow{3}{*}{ Low altitude } & T-I & 8.4 \\
\hline & T-II & 9.2 \\
\hline & T-III & 13.4 \\
\hline \multirow{3}{*}{ Mid altitude-I } & T-I & 4.2 \\
\hline & T-II & 14.2 \\
\hline & T-III & 15.0 \\
\hline \multirow{3}{*}{ Mid altitude-II } & T-I & 13.3 \\
\hline & T-II & 5.8 \\
\hline & T-III & 14.9 \\
\hline \multirow{3}{*}{ High altitude } & T-I & 7.5 \\
\hline & T-II & 8.3 \\
\hline & T-III & 11.7 \\
\hline
\end{tabular}

A good richness and diversity will describe the height of anthropogenic pressure on the species and this pressure varied from elevation to elevation which will be a good tool for management of biosphere reserve in future. In general, the number of tree species was much lower in disturbed stand of $1780 \mathrm{~m}, 2190 \mathrm{~m}$ and $2730 \mathrm{~m}$ than in 1670 $\mathrm{m}$. This could be attributed to heavy extraction of tree species for use as fuel or timber.

The decrease in number of seedlings and saplings from undisturbed stand (15853580 and 1030-1455, respectively) to disturbed stands (2000-2120 and 750-1050, respectively) was observed. However, in general the number of seedlings and saplings remained reasonably high even in disturbed sites. Number of such saplings was lower than the number of seedlings in the present study, which might be due to the inability of all seedlings to graduate into saplings, reasonably affected either by adverse microclimatic factors or by some human related disturbances. Whereas, the seedlings could possibly be trampled out either by men or by the grazing animals. The higher number of seedlings and saplings in disturbed stand than undisturbed stand at $2730 \mathrm{~m}$ could be attributed to the fact that snow lasts for more time in undisturbed stand. And the places were also quite rocky. This could possibly damage both seedlings and saplings or other microclimatic factors provide additional stress.

Woody biomass (branch + bole) was maximum in undisturbed stands of all elevations. It was in the range of 325.8-436.7 $\mathrm{t} \mathrm{ha}^{-1}$ in undisturbed stand, 195-317.5 $\mathrm{t} \mathrm{ha}^{-}$ 1 in partially undisturbed stand, and 65-272.5 $\mathrm{t} \mathrm{ha}^{-1}$ in disturbed stand. The woody biomass in disturbed stand selected in $2730 \mathrm{~m}$ elevation was much lower $\left(65.0 \mathrm{t} \mathrm{ha}^{-1}\right)$ than the biomass in disturbed stands of other elevations (173.3-272.5 $\left.\mathrm{t} \mathrm{ha}^{-1}\right)$. The confidence interval for standing biomass appeared $95 \%$ at 0.05 significance level. It was observed that tree species like Machilus edulis had a higher standing biomass as compared to other tree species even in disturbed stand. This could be the result of thinning of canopy cover that might have provided the opportunity for abnormally higher growth of such species. Furthermore, such species are neither preferred for 
firewood nor fodder. Values of standing biomass (bole + branch) were lower and increment were comparable with the findings of Chettri et al. (2002) in their study of two forest conditions in Yuksam-Dzongri trekking corridor, Sikkim, India. Values of yearly increment in bole (4.2-15.0 $\mathrm{t} \mathrm{ha}^{-1} \mathrm{yr}^{-1}$ ) calculated in the present study were within the range reported by Garkoti and Singh (1995) for the Central Himalayan forests of high altitudes. Buffer zone III and IV was in healthy state and people-area interaction worked within a control. The anthropogenic impact in the buffer zones seems to be more pronounced at lower elevations that have proximity to the human settlements.

Table 8. Allometric equation: Estimation of wood biomass of the major tree species using the following exponential regression equations developed for the temperate forests (after Sundriyal et al. 1994)

\begin{tabular}{c|c|c|c|c}
\hline Species & Regression equation & df & r & E \\
\hline \multicolumn{5}{c|}{ Temperate forest } \\
\hline Alnus nepalensis & $\mathrm{Y}=\exp \left(-2.847+0.839 \ln \mathrm{D}^{2} \mathrm{H}\right)$ & 8 & $0.967^{*}$ & 1.030 \\
Castanopsis tribuloides & $\mathrm{Y}=\exp \left(0.807+0.595 \ln \mathrm{D}^{2} \mathrm{H}\right)$ & 38 & $0.908^{*}$ & 1.049 \\
Eurya acuminata & $\mathrm{Y}=\exp \left(1.165+0.514 \ln \mathrm{D}^{2} \mathrm{H}\right)$ & 19 & $0.860^{*}$ & 1.073 \\
Quercus lamellosa & $\mathrm{Y}=\exp \left(-0.948+0.826 \ln \mathrm{D}^{2} \mathrm{H}\right)$ & 27 & $0.947^{*}$ & 1.077 \\
Symplocos theifolia & $\mathrm{Y}=\exp \left(0.520+0.594 \ln \mathrm{D}^{2} \mathrm{H}\right)$ & 17 & $0.935^{*}$ & 1.066 \\
Other species & $\mathrm{Y}=\exp \left(-0.427+0.719 \ln \mathrm{D}^{2} \mathrm{H}\right)$ & 24 & $0.915^{*}$ & 1.120 \\
\hline
\end{tabular}

Abbreviations used: $\mathrm{Y}=$ Woody biomass (bole and branch) $(\mathrm{kg}) ; \mathrm{D}=$ Diameter at breast height $(\mathrm{cm}) ; \mathrm{H}=$ tree height $(\mathrm{m}) ; \mathrm{S}=$ Specific wood density $\left(\mathrm{g} \mathrm{cm}^{-3}\right)$; $\mathrm{df}=$ degree of freedom; $\mathrm{r}=$ coefficient of correlation; and $\mathrm{E}=$ relative error calculated as antilog of the standard error of the natural logarithm of the $\mathrm{y}$ value; * These vales were significant at $\mathrm{P}<0.001$ level; $\exp =$ exponential

\section{Management aspects}

This is important to understand if inhabitants in KBR fringe areas draw extensively upon any species for their resource use, this may become the major cause of loss of species richness and diversity of the KBR forest cover. Resource use forms an integral part of KBR buffer zone forests and various anthropogenic activities are causing a sustained pressure. Loss of species of interest close to the villages may always create concerns and BR may need attention to avoid this. However, the biosphere managers may not properly perceive such changes. In fact, not many studies considering longerterm consequences have been made of a known human interference on species regeneration. In order to promote natural regeneration, species must be allowed to multiply without human induced disturbance. This can only be possible by developing a sense of belongingness. Judicious harvest of plant parts can be more sustainable than harvest of whole adults, as is often the case when timber is harvested. Selective felling of trees and concurrent plantations of fuelwood, fodder and timber species would mitigate the pressure on forest thus improve their condition over time.

A detailed listing of inventory at species level including their various uses also is required before any successful conservation plan can be undertaken. The assessment of biological importance, status of the habitats and ecosystems of such Himalayan protected areas is needed to identify gaps in conservation and protection. Steps undertaken to counter the adverse effects of disturbance, fragmentation and degradation 
of the remaining wilderness areas should pursue this. Such actions shall help to preserve the diversity and habitats of reserve in harmony with fulfilling resource needs of resident population around the biosphere reserve. Since this BR is in its inception stage, for an effective management and conservation should provide alternate livelihood opportunities and resources to mitigate ongoing rate of exploitation.

Impact assessment of dynamic anthropogenic activities over the years can be derived from using pertinent tools which could identify the overall trends of development and their consequences, such as, changes in landuse from forest to agriculture; level of degradation or regeneration of forest as a consequence of activities such as logging, fuelwood and fodder collection. Thus, this study has generated preliminary information on vegetation composition, regenerating species, biomass and yearly increment.

\section{Conclusions}

This study on resource use impacts of the forest cover of Khangchendozonga Biosphere Reserve (KBR) was carried out despite many constraints such as the arduous fieldworks, inhospitable terrain and lack of adequate resources. Database thus generated should serve as the baseline data for more elaborate studies in future for a hitherto less explored new BR. This may also be used towards better resource management plans of KBR. In future too, such studies should continue for effectively reflecting the ground level issues and design suitable work plan for PAs. There is an indication in this study that resource use pressures presently may eventually lead to substantial impacts on KBR forest cover vegetation. For curbing such future impacts, regular analysis of the ongoing changes as well as identification of gaps for conservation should be essential.

For defraying resource use pressures, promoting conservation and appropriate natural resources management, there is a need to foster better BR management practices. This can be achieved upon creating awareness initially, undertaking capacity building and establishing strict sense of belongingness amongst the resident population as well as the Biosphere managers. Such initiatives will be sustainable only if it is carried out through stakeholders' participation and deploying an evolved form of PA management system for this BR based on experiences from other mountain biosphere reserves of the world. Such an approach for reducing resource use impacts along different disturbance levels and altitudinal zones of this BR should go a long way in promoting BR concept of conservation as well as sustainable management of BR natural resources vis-à-vis conflict prevention.

Acknowledgements. Authors are highly grateful to Dr. L.M.S. Palni, Director, G.B. Pant Institute of Himalayan Environment and Development, Almora, for availing all kinds of laboratory and institutional facilities. Ministry of Environment and Forests, Government of India gave financial assistance in the form of a Project. Department of Forests, Environment and Wildlife Management, Government of Sikkim is also duly acknowledged for cooperation. Pipon (head of village council, Dzumsha) and members of local Panchayats helped us in our field works. 


\section{REFERENCES}

[1] Aigner, P.A., Block, W.M., Morrison, M.L. (1998): Effect of firewood harvesting on birds in a California oak-pine woodlands. -Journal of Wildlife Management 62: 485-496.

[2] Anderson, J.M., Ingram, J.S.I. (1993.):Tropical Soil Biology and Fertility. - A hand book of methods. CAB, International U.K.

[3] Block, W.M., Brennan, L.A. (1993): The habitat concept in ornithology. Theory and applications. - Current Ornithology 11: 35-91.

[4] Bonham, C. (1989): Measurement for Terrestrial Vegetation. - John Wiley and Sons, N.Y.pp. 338.

[5] Chettri, S. (2005): Impact of Anthropogenic Pressure on the Natural Resources of Khangchendzonga Biosphere Reserve with Particular Reference to Buffer Zone. - Ph.D. Thesis, Kumaun University, Naini Tal, India.

[6] Chettri, S., Krishna, A.P., Singh K.K. (2002): Ecosystem conservation prospects in the Khangchendzonga Biosphere Reserve, Sikkim. - In: Krishna, A.P., Rai, P.D., Subba, J. (ed.) Compendium of case studies for South Asia Regional Conference on Ecotouris. Published by Ecotourism and Conservation Society of Sikkim, Gangtok, India, Pp. 41-52.

[7] Chettri, S.K., Singh, K.K.,Krishna, A.P. (2006): Anthropogenic pressures on the natural resources in fringe areas of Khangchendzonga Biosphere Reserve. - International Journal of Ecology and Environmental Sciences 32(3): 229-240.

[8] Congden, R.A., Herbohn (1993): Ecosystem dynamics of disturbed and undisturbed sites in north Queensland wet tropical rain forest: Floristic composition, climate and soil chemistry. - Journal of Tropical Ecology 9: 349-363.

[9] Curtis, J.T., Cottam, G. (1956): The use of distance measure in phyto-sociological sampling. - Ecology 37: 451-460.

[10] Garkoti, S.C., Singh, S.P. (1995): Variation in net primary productivity and biomass of forests in the high mountains of central Himalaya. - Journal of Vegetation Science 6: 2328.

[11] Geldenhuys, C.J., Murray, B. (1993): Floristic and structural composition of Hanglip forest in the South-Pansberg, Northern Transvaal. - South African Forestry Journal 165: 9-20.

[12] Grier, C.C., Logan, R.S. (1997): Old growth Pseudotsuga menziesii communities of the western Oregon watershed: biomass distribution and production budget. - Ecological Monograph 47: 373-400.

[13] Griffin, J.R., Muick, P.C. (1990): California native oaks: Past and present. - Fremontia 18: 4-11.

[14] Jain, A. (2000): Study of Khacheopalri Lake Ecosystem in the Sikkim Himalaya. - Ph.D. Thesis, University of North Bengal, India.

[15] Kadavul, K., Parthasarathy, N. (1998): Biodiversity of woody species and conservation of tropical semi-evergreen forest in Kalrayan Hills, Eastern Ghats, India. - Tropical Ecology 8: 421-439.

[16] Kapoor, K.S., Nath, S., Banerjee, S.P., Banerjee, S.K. (1989): Forest Vegetation of Darjeeling Himalayas-An Analysis. - Van Vigyan 27(1): 24-33.

[17] Krishna, A.P., Chhetri, S., Singh, K.K. (2002): Human dimensions of conservation in the Kangchendzonga biosphere reserve: the need for conflict prevention. - Mountain Research and Development 22(4): 328-331.

[18] Lepcha, G. (1997): Khangchendzonga Biosphere Reserve (Proposal). - Department of Forest, Government of Sikkim.

[19] Maikhuri, R.K., Nautiyal, S., Rao, K.S., Chandrasekhar, K., Gavali, R. Saxena, K.G. (2000): Analysis and resolution of protected area-people conflicts in Nanda Devi Biosphere Reserve, India. - Environmental Conservation 27(1): 43-53.

[20] Margalef, D.R. (1957): Information theory in ecology. - Memorias de la Real Academia de Ciencias y Artes de Barcelona 23: 378-449. 
[21] Mueller Dombois, D., Ellenberg, H. (1974): Aims and Methods of Vegetation Ecology. John Wiley, New York.

[22] Parthasarathy, N. (2001): Changes in forest composition and structure in three sites of tropical evergreen forest around Sengaltheri, Western Ghats. - Current Science 80(3): 389-393.

[23] Philips, E.A. (1959): Methods of Vegetations Study. - A Holt-Dryden Book. Henry Holt and Co., Ina.

[24] Ruark, G.A., Martin, G.L., Bockheim J.G. (1987): Composition of constant and variable allometric ratios for estimating Populus tremuloides biomass. - Forest Science 33: 294300.

[25] Sarkar, S., Margule, C. (2002): Operationalsing biodiversity for conservation planning. Journal of Bioscience (Suppl. 2) 27(4): 299-308.

[26] Shannon, C.E., Wiener, W. (1963): A Mathematical Theory of Communication. University of Illinois press, Urbana.

[27] Sharma, E. (1997): Socio-economic Issues Related to Conservation of the Kanchanjunga Mountain Ecosystem. - In: Rastogi, A., Shengji, P., Amatya, D. (ed.) Regional Consultation on Conservation of the Kanchanjunga Mountain Ecosystem. - WWF-Nepal and ICIMOD, Kathmandu. Pp. 45-52.

[28] Simpson, E.H. (1949): Measurement of Tree Diversity. - Nature 163: 688.

[29] Singh, H.B. (2000): Grazing Impact on Plant Diversity and Productivity along a Tourist Trekking Corridor in the Khangchendzonga Biosphere Reserve of Sikkim. - Ph.D.Thesis, University of North Bengal, India.

[30] Singh, S.P., Adhikari, B.S., Zobel, D.B. (1994): Biomass, productivity, leaf longevity and forest structures along an altitudinal gradient in the Central Himalaya. - Ecological Monographs 64(64): 401-421.

[31] Sundriyal, R.C., Rai, S.C., Sharma, E., Rai, Y.K. (1994): Hill agroforestry systems in South Sikkim, India. - Agroforestry Systems. 26: 215-235.

[32] Sundriyal, R.C., Sharma, E. (1996): Anthropogenic pressure on tree structure and biomass in the temperate forest on Mamlay watershed in Sikkim. - Forest Ecology and Management 81(1-3): 113-1134.

[33] Systat.(1996): Statistics. Systat 6.0 for Windows. SPSS Inc., Chicago.

[34] Trivedi, R.K., Goel, P.K., Trisal, C.L. (1987): Practical Methods in Ecology and Environmental Science. - ENVIROMEDIA, Karad, India.

[35] Whitford, P.B. (1949): Distribution of woodland plants in relation to succession and clonal growth. - Ecology 30: 199-208.

[36] Whittaker, R.H. (1975): Communities and Ecosystems. - Second edition. Macmillan, New York, New York, USA. 